\title{
Aspectos psicológicos del humorismo
}

\author{
Psychological aspects of humor
}

Pedro Albùjar-Baca ${ }^{1}$

\section{Resumen}

El autor nos esboza algunos conceptos sobre el humorismo a través de los chistes en la vida cotidiana, porque la risa es un indicador del estado de felicidad de una persona.

Palabras claves: psicología, humorismo, chiste, risa.

\section{Abstract}

The author outlines some concepts about humorism through jokes in everyday life, because laughter is an indicator of a person's state of happiness.

Keywords: psychology, humor, joke, laughter.

Después del llanto con que se nace a la vida, la sonrisa es una de las primeras manifestaciones de un recién nacido. La capacidad de reír es un indicador del estado de felicidad de un ser humano. Históricamente, se encuentra muchas referencias de médicos y filósofos que han cultivado literariamente la alegría como fuente de placer y salud, desde Hipócrates y Platón hasta tratados sobre la risa como los de Laurent Joubert en el siglo XVI y Schopenhauer y Bergson en el siglo XIX. Sigmund Freud $^{1}$ en 1973 aborda con gran lucidez el tema del humorismo en su obra El chiste y su relación con el inconsciente.

1 Ex decano de la Facultad de Ciencias Médicas, Universidad Nacional de Trujillo, Perú.

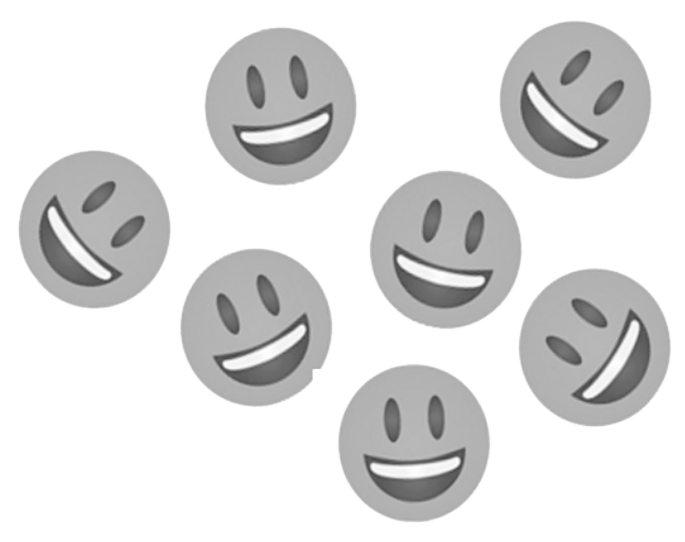

El chiste tiene dos características esenciales: la brevedad y la elipsis o supresión intencionada de palabras innecesarias. ${ }^{2}$ Según Freud, el chiste desencadena un singular proceso psíquico que acumula tensión y finaliza con su descarga.

El chiste es una ocurrencia que surge por afloración de elementos del inconsciente a la conciencia. Es el caso de un presidiario que va a ser colgado en la horca un lunes, ante esta situación el reo clama: "¡Bonita manera de comenzar la semanaj” Lo que hace el preso en esa situación es enfrentar dramáticamente resignado a la realidad mediante un acto de humorismo.

Hay dos variedades de chiste: por superación y por alusión. Un ejemplo de la variedad por 
superación es el de un casamentero que presenta a su cliente la mujer que le ha escogido como novia. Desagradablemente, impresionado el joven le dice a su gestor:

- ¿Para qué me ha traído, usted aquí? es fea, vieja, bizca y desdentada y...

- Puede usted hablar más alto-interrumpe el agente- también es sorda. ${ }^{3}$

En la variedad por alusión los elementos del chiste son más manejables. Un judío que ve restos de comida en la barba de otro judío, le dice:

- $\quad$ A que adivino qué has comido ayer.

- Dilo.

- Lentejas.

- Perdiste -le responde el segundo- Eso fue anteayer.

La condensación del enunciado de un chiste mejora su propósito. Una madre le dice su hijo:

- Deberías ser como tu hermano, fíjate cómo estudia.

- $\quad$ No sé por qué dices eso mamá. Yo soy más estudioso que él, he repetido el quinto año cinco veces.

Según Freud el chiste es una actividad que tiende a extraer placer de los procesos psíquicos. Los chistes pueden ser tendenciosos o no tendenciosos llamados también inocentes.
El chiste tendencioso se caracteriza por ser hostil, agresivo u obsceno. Así, en una familia el padre estaba exageradamente orgulloso de su mujer por haberle dado seis hijos, tanto que la llamaba "madre de seis", lo que molestaba muchísimo a la esposa. Un día que se encontraban en una boda, el padre le grita para que todos escucharan:

- ¿Ya estás lista para irnos madre de seis?

Con furia su esposa contesta:

- $\quad$ Claro que sí, padre de cuatro.

En los chistes inocentes se utiliza el juego de palabras. Por ejemplo: "No solo no creía en fantasmas, sino que ni siquiera se asustaba de ellos" Cierro esta breve nota con la esperanza que estas divagaciones sobre el humor incentiven en ustedes el cultivo del mismo.

\section{Referencias bibliográficas}

1. Freud S. El chiste y su relación con el inconsciente. Madrid: Edit. Alianza S.A., 1973, 223 p.

2. García Serrano, Federico. Humor y psicoanálisis; una lectura de los textos de Freud. Facultad de Psicología. Universidad Complutense, Madrid. Septiembre 2006, 196 p.

3. Serrano Serrano, Joaquín. El uso de la lengua en los chistes. Estudios humanísticos. Filología. 2016,38:195.

\section{Correspondencia:}

Pedro Albújar-Baca

albujarb@yahoo.es

Fecha de recepción: 12-05-2021.

Fecha de aceptación: 20-08-2021.

Conflicto de interés: ninguno, según el autor.

Financiamiento: por el autor. 